\title{
Provisions in Metallurgical Industry and Financial Crisis ${ }^{\#}$
}

\author{
Michal BOBEK
}

Provisions are common part of financial statements. There is not a must to disclose provisions - on the other hand - it is advisable to do so because of future expenses of "uncertain amount and timing" which can be expected. Provisions can be influenced very easily because of their very nature - they are just the best estimates of expenses the real height of which is currently unknown. The focus of this article's research is on the provisions in metallurgical industry: whether companies disclose provisions, in which amount and how has the financial crisis influenced disclosure of provisions.

\section{Provisions}

The main specific feature of metallurgical industry is the huge initial investment and its long term horizon. The main operational investments are used for long time and the need for the investments is outstanding in this sector (Hutnictví železa, 2013). Therefore, as the same source adds, also the return of investment is long-term and the purpose of investment cannot be easily changed without loses and write-offs. The companies operating in the business are raw materials and energy demanding. The publication Hutnictví železa (2013) stresses the need for short-term bank loans for financing of stocks. This information could be supported by the calculations from SOLIDITET (2013): the ratio short-term debt/total assets represents on average $6.6 \%$ (the weighted arithmetic mean used).

\# The research has been supported as one of the products of the research project of The Faculty of Finance and Accounting at University of Economics, Prague, realized in the framework of the institutional support IP100040.

This article builds on the paper Provisions in the Metallurgical Industry in the Czech Republic which was presented on the 22nd International Conference on Metallurgy and Materials - Metal2013. This article uses some findings from the paper and comments made on it during the conference.

Ing. Michal Bobek, MBA - Ph.D. student; Department of Corporate Finance and Valuation, Faculty of Finance and Accounting, University of Economics, Prague, W. Churchill Sq. 4, 13067 Prague 3, Czech Republic, <xbobm04@vse.cz>. Senior Audit Assistant, Rödl \& Partner Audit, s.r.o. 
The calculation of Ministry of Industry and Trade (2013) calculates that the ratio for manufacturing industry is only $3 \%$.

The steel industry rapidly grows globally. According to the World Steel Association (2012), the production of steel grew by $81 \%$ (2001: 851 megatons, 2012: 1548 megatons) and consumption of steel grew by $43 \%$ (2001: $150 \mathrm{~kg}$ per capita, 2012: $215 \mathrm{~kg}$ per capita) in the last decade. The industry employs 50 million people worldwide (both directly and indirectly). However, the position of European metallurgical industry goes down. As ECORYS (2008, p. iii) refers, the European steel production was $24.3 \%$ of world production in 1997, but only $16 \%$ in 2007. According to this report, the European metallurgical industry challenges the world consumption changes and should be consolidated.

The study of competitiveness of European metallurgical industry (ECORYS, 2008, pp. iv - vi) describes five challenges for European metallurgical industry:

- The center of steel industry has been shifting to the "East" especially the consumption of steel is in the developing countries in the East and new active players from these countries have been emerging.

- Growing prices of raw material and Europeans' dependence on import of raw material.

- Trade policies - restrictive policies for entering some markets, especially in developing countries.

- Asymmetric environmental regulation - the regulation in the European Union is more strict than the regulation in developing countries.

- The shortage of educated and skilled employees.

The companies operating in the steel industry could be divided into three groups: (i) global players, (ii) regional champions and (iii) niche specialists (Boston Consulting Group, 2007). Albeit the report is a little bit outdated because of the financial crisis, we can expect that the main characteristic stayed unchanged. According to the report, the global players are integrated around the world, using the potential of both developing (low cost production) and developed countries (research and development, know-how, IT technology). A global player has to be able to produce more than 50 million tons of steel. According to the BCG (2007), ArcelorMittal was the only global player in 2007. The regional champions are situated in specific region and are able to produce between 10 and 50 million tons of steel. The example should be ThyssenKrupp, 
according to the ECORYS (2008). The niche specialists produce less than 5 million $^{1}$ tons and they are located in developed countries producing very specific steel with high margin. The BCG (2007, p. 23) adds that the industry has been consolidated and there is a further trend of consolidation. In 2007, the top 10 producers of steel occupied $28 \%$ of the world steel production. The further consolidation of metallurgical industry will be influenced mainly by the Chinese government's effort for consolidation (Ernst \& Young, 2013, p. 23).

\section{Czech metallurgical industry}

As Hutnictví železa (2013) states, Czech metallurgical industry was considerably extensive before the Velvet Revolution. As the Czech Republic was specialized on this industry in the framework of the Eastern Bloc, the industry produced 10.6 million tons of steel here in 1989 (Hutnictví železa, 2013). The revolution in 1989 dramatically changed the political and economic reality. Czech metallurgical companies lost their markets in former USSR and they became subject of a huge transformation. The transformation lowered capacity of industry and brought in private equity. Some privatization projects were not successful and many companies were closed (Hutnictví železa, 2013). The producing companies were restructured and reduced. Now, the industry is characterized by three large companies (ArcelorMittal Ostrava a.s., TŘINECKÉ ŽELEZÁRNY, a. s. and EVRAZ VÍTKOVICE STEEL, a.s.). These companies dominate this industry in the Czech Republic from both the total assets and sales points of view. ArcelorMittal Ostrava a.s. and TŘINECKÉ ŽELEZÁRNY, a. s. have their own blast furnaces, and the EVRAZ VÍTKOVICE STEEL, a.s. buys iron from ArcelorMittal Ostrava, a. s. Other companies operating in this industry are much smaller than these three companies (calculation from SOLIDITET, S, 2013).

\section{Provisions}

Provisions are defined in the IAS 37, IN 2, Part A as "liabilities of uncertain timing or amount". The obligation has to be result of past events, the amount of provision should be a reliable estimate and there is probability of outflow of sources of entity. The probability is defined as "more likely than not". This definition is used from International

1 The Boston Consulting Group (2007, p. 29) does not state any information for businesses producing $5-10$ millions of tons of steel. 
Accounting Standard, because it presents the basis of provisions better, that e.g. the Czech GAAP definition.

The definition of provisions contents many conditions which have to be met to recognize provisions. This accounting category has to be estimated, however, there is not a special key for estimating them. The standard brings examples and describe special purposes (e.g. an onerous contract - IN 12, restructuring - IN 13, future operating loses - paragraph 18, IAS 37, Part A). The definition of probability ("more likely than not") is very vague and offers space for possible creative accounting. The detailed description of provisions is offered in IAS 37, or in Czech language in Bobek (2012).

The Czech accounting system uses, with respect to some differences, the same definition of provisions. However, the CZ GAAP sets strict rules for disclosing of provisions in financial statements. Therefore, there are exact positions for provisions in the balance sheet according to $\mathrm{CZ}$ GAAP. The differences between CZ GAAP and IAS/IFRS were described in Bobek (2012).

\section{Provisions in the metallurgical industry}

The aim of this article is to research development of provisions in the metallurgical industry in the Czech Republic. Czech companies can use CZ GAAP and in rare cases IAS/IFRS methodology for accounting (the companies issuing financial instruments according to Act 256/2004 Coll.). However, they are obliged to use only CZ GAAP for determining the income tax. Therefore, IAS/IFRS is used by Czech companies only if they are obliged to do it.

Provisions are part of liabilities which is of uncertain timing and amount. It is not rule that companies have to recognize a provision - it is dependent on their particular situation. Metallurgical industry should recognize provisions for repairs (according to the Czech special legislation) and provisions for environmental damages.

\section{Methodology of research}

The analysis uses data from Albertina Database (SOLIDITET, S.R.O., 2013) - financial statements for CZ NACE 24, however only of those companies whose operating activities are mainly in this area. The first set of data was obtained on February 23, 2013, the new set is from 
September 30, 2013. Because the new set did not contain the old data for year 2004, both databases were combined.

The data were adjusted. The companies disclose financial statements according to the CZ GAAP, therefore the financial statements of following qualities were excluded:

- according IAS/IFRS (12 records),

- with negative or null assets (10 records) and

- with the period which was shorter or equal 4 and longer or equal 16 months (63 records).

The research is based on 1784 individual records and is prepared according to the Czech GAAP (therefore it will not be possible to study the long-term provisions, for example). There are around 200 records for every individual year of the analysis. The database contains 335 individual companies. One company presents on average 5.3 financial statements (arithmetical mean) in the database and the mode of database is 8. The period for research is between 2004 and 2011. There is a small sample for year 2012 (13 records) as well, however the sample is too small for the analysis, therefore the analysis will end in 2011. All the analyses are prepared on the level of individual records and the ratios are counted in such a way. Due to the methodology, each record is counted with the same significance. The geometrical mean is used for counting of most of the ratios. The choice of the period enables to judge the general trend and the influence of financial crisis.

The research is prepared from the point of view of the number of provisions and amount of provisions. The number of provisions means the number of financial statements including these provisions which are counted and analyzed. The amount of provisions represents provisions which are compared to other figures and ratios and analyzed. The companies were divided into three groups:

- large companies (total assets more than 1 billion CZK),

- middle-sized companies (total assets between 100 million and 1 billion CZK), and

- small companies (total assets less than 100 million CZK).

The size of companies is used in some analyses because the disclosure of provisions can differ in relation to the size of companies. 


\section{Number of disclosed provisions}

The provisions were disclosed in less than half of financial statements in all individual years and the trend is further descending. The descending trend started in 2004 and has continued throughout the whole period. The geometric mean of pace of the descent is $4.68 \%$. The trend of nondisclosure of provisions was not stable and the influence of financial crisis is not visible.

Tab. 1: The number of financial statements containing provisions

\begin{tabular}{|c|c|c|c|c|c|c|c|c|}
\cline { 2 - 9 } \multicolumn{1}{c|}{} & $\mathbf{2 0 0 4}$ & $\mathbf{2 0 0 5}$ & $\mathbf{2 0 0 6}$ & $\mathbf{2 0 0 7}$ & $\mathbf{2 0 0 8}$ & $\mathbf{2 0 0 9}$ & $\mathbf{2 0 1 0}$ & $\mathbf{2 0 1 1}$ \\
\hline A & $46.51 \%$ & $45.45 \%$ & $45.37 \%$ & $39.56 \%$ & $36.97 \%$ & $33.47 \%$ & $30.74 \%$ & $25.44 \%$ \\
\hline B & $53.49 \%$ & $54.55 \%$ & $54.63 \%$ & $60.44 \%$ & $63.03 \%$ & $66.53 \%$ & $69.26 \%$ & $74.56 \%$ \\
\hline C & & $2.27 \%$ & $0.20 \%$ & $12.81 \%$ & $6.52 \%$ & $9.48 \%$ & $8.15 \%$ & $17.24 \%$ \\
\hline
\end{tabular}

Source: SOLIDITET (2013), authorial computation.

Explanatory notes: $\mathrm{A}=$ Disclosure of provisions, $\mathrm{B}=$ Without disclosure of provisions; $\mathrm{C}=$ The pace of descending of disclosure.

The trend of disclosure of provisions was compared to the statistical indexes of the Czech Republic (its Gross domestic product and Industrial producer prices - Czech statistical Office, 2013) and of the European Union (GDP of Germany and of 27 member states of the European Union - Eurostat, 2013). It was discovered that there was dependence on the GDP of the Czech Republic (0.64) and on the GDP of 27 member states of the European Union (0.39). According to these results we can draw partial conclusion that disclosure of provisions depends on economic growth of the Czech Republic as of the domestic environment and of member states of European Union as of the most important business partner $^{2}$ of the Czech Republic.

The disclosure of provisions was examined from the company size's point of view. The companies disclosing provisions are usually larger the geometric mean for individual years shows that the companies disclosing provisions are 13.1 times larger than those not disclosing provisions (the number of companies disclosing/not disclosing provisions was taken into consideration for this computation). According to change of trend, it is advisable to divide the period into two sub-periods. The first

2 The most important partner of the Czech Republic in external trade is the European Union. The turnover was $73.7 \%$ of all external trade in 2012. The turnover of Germany was $29.0 \%$ in 2012 (Czech Statistical Office, 2013a). 
sub-period lasted from 2004 to 2007 and the companies disclosing provisions were 8.75 times larger than the not disclosing ones. The other sub-period lasted from 2008 to 2011 and the disclosing companies were 19.56 times larger than the not disclosing ones. It is possible to draw the partial conclusion from these results expressing that smaller companies rapidly lowered number of disclosed provisions after the start of the financial crisis.

The next analysis examined the number of provisions based on the companies' size. The large companies disclosed provisions on regular basis and the financial crisis or other factor did not influence it. As it is visible from Tab. 2, 82.73\% of large companies disclosed provisions in their financial statements. The same is valid for middle-sized companies they disclosed provisions regularly, in the time after financial crisis even more often. The decreasing trend of provisions was caused by small companies. The small companies reduced the number of disclosed provisions immediately after 2007. The difference between first and second sub-period is about 20 percentage points. These were those small companies which caused the reduction of disclosed provisions in the whole sample.

\section{Tab. 2: Number of disclosed companies base on the companies' size}

\begin{tabular}{|l|c|c|c|c|}
\hline Companies & A & B & C & D \\
\hline Large & $82.73 \%$ & $82.98 \%$ & $82.48 \%$ & $98.42 \%$ \\
\hline Middle-sized & $57.02 \%$ & $56.62 \%$ & $57.43 \%$ & $94.72 \%$ \\
\hline Small & $18.76 \%$ & $30.41 \%$ & $11.58 \%$ & $17.17 \%$ \\
\hline
\end{tabular}

Source: SOLIDITET (2013), authorial computation.

Explanatory notes: A = Geometrical mean for the period $(2004-2011)$,

$\mathrm{B}=$ Geometrical mean for sub-period $2004-2007$; $=$ Geometrical mean for sub-period 2008 - 2011; D = Comparison 2011/2004.

These results were compared with economic situation of the Czech Republic and European Union (GDP of the Czech Republic, European Union Member States and Germany and the Industrial producer prices of the Czech Republic). The small companies have strong dependence on the development of GDP of the Czech Republic (0.65). There is also a positive correlation for the large companies if we take into account Industrial producer prices $(0.45)$. The correlation coefficient shows strong dependence of disclosed provisions of small companies on the GDP of the Czech Republic. 


\section{Amount of provisions}

The first part has presented the number of provisions which are disclosed in particular financial statements. This analysis focuses on amount of disclosed provisions in particular financial statements. The companies' size was taken into consideration.

Tab. 3: Provisions / assets ratio

\begin{tabular}{|l|l|l|l|l|l|l|l|l|}
\cline { 2 - 9 } \multicolumn{1}{c|}{} & $\mathbf{2 0 0 4}$ & $\mathbf{2 0 0 5}$ & $\mathbf{2 0 0 6}$ & $\mathbf{2 0 0 7}$ & $\mathbf{2 0 0 8}$ & $\mathbf{2 0 0 9}$ & $\mathbf{2 0 1 0}$ & $\mathbf{2 0 1 1}$ \\
\hline A & $1.43 \%$ & $1.79 \%$ & $0.81 \%$ & $1.18 \%$ & $0.76 \%$ & $1.15 \%$ & $0.66 \%$ & $0.85 \%$ \\
\hline B & $1.35 \%$ & $2.11 \%$ & $1.62 \%$ & $1.52 \%$ & $1.29 \%$ & $0.82 \%$ & $0.68 \%$ & $0.69 \%$ \\
\hline C & $5.46 \%$ & $4.04 \%$ & $4.87 \%$ & $4.34 \%$ & $4.54 \%$ & $2.58 \%$ & $2.75 \%$ & $3.12 \%$ \\
\hline D & $2.46 \%$ & $2.69 \%$ & $2.20 \%$ & $2.07 \%$ & $1.73 \%$ & $1.21 \%$ & $0.90 \%$ & $0.93 \%$ \\
\hline
\end{tabular}

Source: SOLIDITET (2013), authorial computation.

Explanatory notes: $\mathrm{A}=$ Large companies, $\mathrm{B}=$ Middle-sized companies; $\mathrm{C}=$ Small companies; $\mathrm{D}=$ All the records.

The importance of provisions in particular financial statements depends on the companies' size. The importance is larger in smaller companies. On the other hand, provisions are not so important for larger companies. The middle-sized companies are similar to the large companies - provisions are not so important part of their equity and liabilities. Provisions are the most important part of financial sources of small companies.

The amount of provisions fell immediately after 2007 (except for small companies). Using the geometrical mean, the greatest fall was observed for middle-sized companies $(1.63 \%$ for the sub-period 20042007 and $0.84 \%$ for the sub-period 2008-2011). The development was very similar for large companies as well. The decrease of amount of provisions was not so rapid in case of small companies.

The previous analysis leads to the result, that the financial crisis has an influence on the amount of provisions. The situation could be influenced by adopting of new Act 593/1992 Cool, as it is stated in the next part of the analysis (concerning types of provisions). To prove this, the analysis was repeated, however, this time without the provisions under special legislation. As the analysis shows, the large companies have relatively stable development without any visible trend. However, smaller companies started to reduce the number of provisions after 2007 (middlesized companies) and 2008 (small companies). The reduction is more important for middle-sized companies rather than for the small ones. We 
can draw conclusion that the large companies were not influenced by the financial crisis - the fall of amount was caused by the provisions under special legislation (the change of act). On the other hand, the middle-sized and small companies were influenced by the financial crisis - the amount of provisions without provisions under special legislation fell after start of the financial crisis. The delay in the trend of small companies in relation to other types of companies is not explained.

Tab. 4: Provisions without provisions under special legislation / assets ratio

\begin{tabular}{|l|l|l|l|l|l|l|l|l|}
\cline { 2 - 9 } \multicolumn{1}{c|}{} & $\mathbf{2 0 0 4}$ & $\mathbf{2 0 0 5}$ & $\mathbf{2 0 0 6}$ & $\mathbf{2 0 0 7}$ & $\mathbf{2 0 0 8}$ & $\mathbf{2 0 0 9}$ & $\mathbf{2 0 1 0}$ & $\mathbf{2 0 1 1}$ \\
\hline A & $1.35 \%$ & $0.93 \%$ & $0.49 \%$ & $0.73 \%$ & $0.61 \%$ & $0.83 \%$ & $0.78 \%$ & $1.22 \%$ \\
\hline B & $0.80 \%$ & $1.16 \%$ & $0.94 \%$ & $0.91 \%$ & $0.70 \%$ & $0.60 \%$ & $0.54 \%$ & $0.66 \%$ \\
\hline C & $3.00 \%$ & $1.66 \%$ & $2.23 \%$ & $2.34 \%$ & $2.61 \%$ & $1.13 \%$ & $1.38 \%$ & $1.82 \%$ \\
\hline D & $1.37 \%$ & $1.24 \%$ & $1.02 \%$ & $1.05 \%$ & $0.91 \%$ & $0.75 \%$ & $0.70 \%$ & $0.90 \%$ \\
\hline
\end{tabular}

Source: SOLIDITET (2013), authorial computation.

Explanatory notes: $\mathrm{A}=$ Large companies, $\mathrm{B}=$ Middle-sized companies; $\mathrm{C}=$ Small companies $; \mathrm{D}=$ All the records.

The provisions proved to be an important part of liabilities of small companies, especially at the beginning of the period. However, the decreasing trend is visible and it is caused by both the reduction of provisions under special legislation and the financial crisis. On the other hand, the importance of provisions as part of liabilities is smaller for large and middle-sized companies. As the provisions could be influenced by the change of provisions under special legislation, the table is prepared once again, now with exclusion of the provisions under special legislation.

Tab. 5: Provisions / liability ratio

\begin{tabular}{|l|l|l|l|l|l|l|l|l|}
\cline { 2 - 9 } \multicolumn{1}{c|}{} & $\mathbf{2 0 0 4}$ & $\mathbf{2 0 0 5}$ & $\mathbf{2 0 0 6}$ & $\mathbf{2 0 0 7}$ & $\mathbf{2 0 0 8}$ & $\mathbf{2 0 0 9}$ & $\mathbf{2 0 1 0}$ & $\mathbf{2 0 1 1}$ \\
\hline A & $2.75 \%$ & $3.73 \%$ & $1.68 \%$ & $2.85 \%$ & $1.83 \%$ & $2.99 \%$ & $1.60 \%$ & $2.39 \%$ \\
\hline B & $2.43 \%$ & $3.85 \%$ & $3.17 \%$ & $2.83 \%$ & $2.67 \%$ & $1.93 \%$ & $1.47 \%$ & $1.59 \%$ \\
\hline C & $9.04 \%$ & $6.78 \%$ & $7.70 \%$ & $7.16 \%$ & $6.84 \%$ & $5.66 \%$ & $3.55 \%$ & $2.65 \%$ \\
\hline D & $4.32 \%$ & $4.83 \%$ & $3.99 \%$ & $3.92 \%$ & $3.34 \%$ & $2.86 \%$ & $1.79 \%$ & $1.94 \%$ \\
\hline
\end{tabular}

Source: SOLIDITET (2013), authorial computation.

Explanatory notes: A = Large companies, B = Middle-sized companies;

$\mathrm{C}=$ Small companies; $\mathrm{D}=$ All the records. 
From this point of view, the amount of provisions of large companies is even growing. As the ratio provisions without provisions under special legislation / assets was stable after beginning of financial crisis and the provisions / liability ratio grows, we can draw the conclusion that metallurgical companies have reduced the number of liabilities after the start of the financial crisis and replaced it by equity. This result provides next arguments for the statement that the provisions of large companies were not influenced by the financial crisis as proven in the analysis which is because (i) the amount of provisions is more important part of liabilities (the liabilities were reduced but the provisions remained unchanged) and (ii) the number of provisions have not changed rapidly since the financial crisis broke up (see part Number of provisions).

\section{Tab. 6: Provisions without provisions under special legislation / liabilities ratio}

\begin{tabular}{|l|l|l|l|l|l|l|l|l|}
\cline { 2 - 9 } \multicolumn{1}{c|}{} & $\mathbf{2 0 0 4}$ & $\mathbf{2 0 0 5}$ & $\mathbf{2 0 0 6}$ & $\mathbf{2 0 0 7}$ & $\mathbf{2 0 0 8}$ & $\mathbf{2 0 0 9}$ & $\mathbf{2 0 1 0}$ & $\mathbf{2 0 1 1}$ \\
\hline A & $2.68 \%$ & $1.93 \%$ & $1.02 \%$ & $1.76 \%$ & $1.53 \%$ & $2.18 \%$ & $1.96 \%$ & $3.60 \%$ \\
\hline B & $1.48 \%$ & $2.13 \%$ & $1.80 \%$ & $1.68 \%$ & $1.32 \%$ & $1.35 \%$ & $1.15 \%$ & $1.53 \%$ \\
\hline C & $5.27 \%$ & $2.99 \%$ & $3.72 \%$ & $4.33 \%$ & $4.22 \%$ & $2.69 \%$ & $2.10 \%$ & $1.86 \%$ \\
\hline D & $2.52 \%$ & $2.33 \%$ & $1.92 \%$ & $2.12 \%$ & $1.82 \%$ & $1.79 \%$ & $1.46 \%$ & $2.04 \%$ \\
\hline
\end{tabular}

Source: SOLIDITET (2013), authorial computation.

Explanatory notes: A = Large companies, B = Middle-sized companies; $\mathrm{C}=$ Small companies; $\mathrm{D}=$ All the records.

The ratio for small and middle-sized companies developed very similarly - after the start of the financial crisis the ratio was reduced. The first reason is an influence of provisions under special legislation. However, the result of analysis excluding the influence of the provisions under special legislation shows a descending trend after the start of the financial crisis as well. The ratio liability / assets shows the same pace of decrease as in the case of the large companies. We can conclude that the middle-sized companies reduced the liability and the amount of provisions was reduced even more. Nevertheless, we are not able to judge the reason (because of hidden reserves or efforts to reduce the expenses for provisions). The ratio liability / assets grew for small companies after 2007. The influence of the financial crisis is clearly visible.

The analysis of turnover of provisions showed that the provisions are marginal for large companies - the turnover is around 400 or more (typically 5000 - 6000). The similar situation can be observed in middle- 
sized companies - the turnover is 250 or larger (typically 400). The strange situation appears in the case of small companies - the turnover is about $100-150$ and the lowest level was before the financial crisis (2006 and 2007). This result supports the conclusion, that provisions were adapted by small companies after the start of the financial crisis.

\section{Analysis of individual types of provisions}

This analysis deals more with individual types of provisions. As financial statements in simplified form do not content this information, the simplified financial statements containing provisions were excluded. The Czech GAAP list four types of provisions which have to be disclosed in financial statements: provisions under special legislation, provisions for pensions and similar payables, income tax provisions and other provisions. The other provisions category represents accounting provisions as presented by the IAS 37 .

\section{Number of individual types of provisions}

Thanks to the detailed analysis of particular provisions, it was found out that the descending trend is typical for all types of provisions. The provisions under special legislation declined very quickly - this type of provisions was included in $23 \%$ of financial statements in 2004, however only in $4 \%$ of them in 2011 . The number of this type was stable until 2007, however the number of provisions started to fall after 2008 in an intense pace ${ }^{3}$. It is important to add that this type of provisions is taxeffective. Therefore, there could be two reasons for these changes: (i) financial crisis which started in the Czech Republic in 2008 and (ii) changes of law. This development could be explained by the promulgation of a new act 593/1992 Cool. which requires saving money in the amount of the provision on a special bank account. The law came into force after December 31, 2008. However, due to the tax, legislation influenced the year 2008 as well. Therefore, the reason for decrease was the changed legislation, not the financial crisis.

The other provisions have descending trend, without any large changes. The other provisions declined by about 2 percentage points during the period. The provisions for pensions and income tax provisions oscillated between $0 \%$ and $2 \%$ (provisions for pensions) and between $2 \%$ and $6.2 \%$ (income tax pensions).

$22 \%$ of financial statements content provisions in 2007 , however only $4 \%$ of them in 2011. 
Fig. 1: The number of disclosed types of provisions

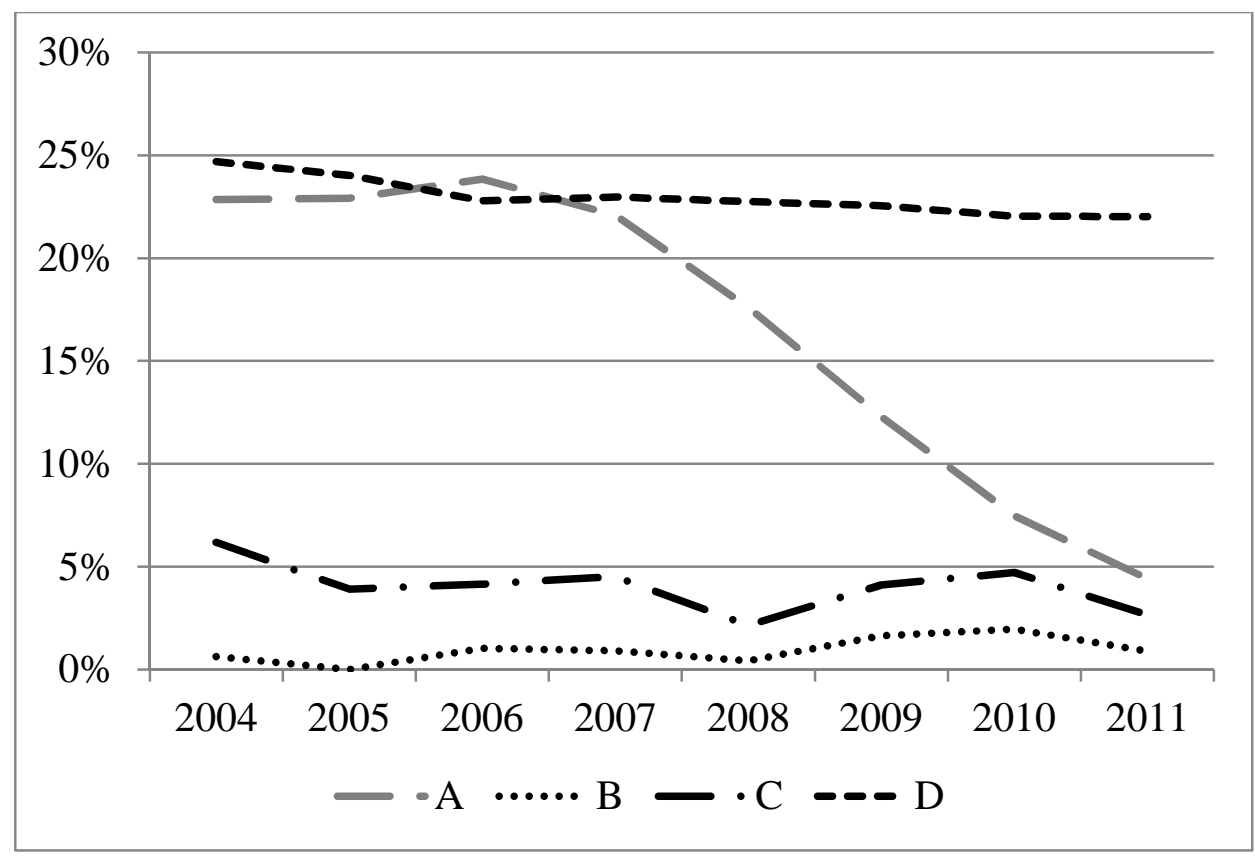

Source: SOLIDITET (2013), authorial computation

Explanatory notes: $\mathrm{A}=$ Provisions under special legislation, $\mathrm{B}=$ Provisions for pensions and similar payments; $\mathrm{C}=$ Income tax provisions; $\mathrm{D}=$ Other provisions

\section{Type of provisions in relation to the companies' size}

Provisions under special legislation

The provisions under special legislation were disclosed especially by larger companies, the small and middle-sized companies disclosed these provisions less. The table shows that the provisions under special legislation declined regardless the size of companies. The larger companies reduced the number of these provisions mainly after 2007, while the first sub-period was stable. These provisions were reduced regularly by about 10 percentage points every year starting in 2009. The same situation could be observed in middle-sized companies -stable development in the first sub-period and decline after 2008. The pace of decline accelerated in 2010 and 2011 especially. The small companies started to reduce the number of these provisions already in 2007. Then, the pace of reduction was relatively stable. The small companies disclose the provisions under special legislation only in $2.03 \%$ of financial statements in 2011. The change of legislation caused lower disclosure for 
companies of all size. Based on that, we can draw a conclusion, that these provisions are recognized only in order to meet the tax legislation and in many cases they do not correspond to the nature of provisions. Especially the small companies use the provisions due to the tax-affect.

Tab. 7: Number of disclosed provisions under special legislation

\begin{tabular}{|l|r|r|r|c|}
\hline Companies & \multicolumn{1}{c|}{ A } & B & C & D \\
\hline Large & $38.48 \%$ & $46.79 \%$ & $31.65 \%$ & $46.32 \%$ \\
\hline Middle-sized & $17.57 \%$ & $25.91 \%$ & $11.92 \%$ & $20.67 \%$ \\
\hline Small & $8.79 \%$ & $17.23 \%$ & $4.48 \%$ & $10.61 \%$ \\
\hline
\end{tabular}

Source: SOLIDITET, S.R.O. (2013), authorial computation.

Explanatory notes: A = Geometrical mean for the period $(2004-2011)$, $\mathrm{B}=$ Geometrical mean for sub-period $2004-2007 ; \mathrm{C}=$ Geometrical mean for sub-period 2008 - 2011; D = Comparison 2011/2004.

Taking into consideration the amount of this type of provisions on the total amount of provisions, these provisions were the most important for small companies. If the small companies recognize provisions, it is only one type of provisions. Very similar situation is for the middle-sized companies. This type of provisions is between about one third and one fourth of the total provisions of large companies. The amount of this type of provisions was reduced after 2007.

\section{Provisions for pensions and similar payables}

Provisions for pensions and similar payables are disclosed only rarely and achieve the peak of $4 \%$. At the beginning of period, the position was not even used by companies. The large companies started to use it after 2007 (immediately in 4\% of financial statements) and the number stayed stable during the rest of the period. The middle-sized companies started to use the position in 2009 (in the beginning in about 3\% of financial statements, the further trend oscillated between $1.5 \%$ and $3 \%$ ). The small companies use the position without any trend. The available sources show that the government prepared first version of pension reform in this year (Zamečník, 2007, Ministry of Labour and Social Affairs, 2007). There is not any mention of pensions paid by companies, however this change could bring an idea of recognizing such a type of provisions.

\section{Income tax provisions}

The income tax provisions are disclosed especially by large companies (geometrical mean $23.57 \%$ of financial statements). Middle- 
sized companies disclose these type of provision less - the geometrical mean for the period, excluding the null value, was $4.97 \%$ and small companies disclose it very rarely. The correlation was used here to discover any dependence on the GDP. The research of correlation shows that large companies' development is dependent on the GDP of the European Union Members (0.52) and the GDP of the Czech Republic (0.31). The research continued with "postponed period" this period the dependence is stronger for large and middle-sized companies (large companies: dependence on the GDP of the Czech Republic 0.54, of EU-Members 0.48; middle-sized companies: GDP of the Czech Republic 0.86, EU-Members 0.84). According to the results, the development of this type of provisions of middle-sized and large companies could be used as an indicator of the future growth of GDP. The amount of disclosed provisions shows that it is the only type of disclosed provisions for many companies (more than $90 \%$ of small and middle-sized companies use it).

\section{Other provisions}

The largest companies did not react to the financial crisis and the number of disclosed provisions in financial statements oscillated between $69 \%$ and $74 \%$ for the period $2004-2010$. These provisions were in $84 \%$ financial statements in 2011, which is the only exception. The middlesized companies increased the number of disclosed provisions after 2007 - the first sub-period is stable, however, there is a visible increasing trend in the second one. The smallest companies have reduced the number of other provisions since 2005. As this type of provisions represents the accounting provisions according IAS 37, we can draw important conclusions: (i) the financial crisis has not influenced the number of provisions of large companies. (ii) The middle-sized companies started to increase the number of provisions after the start of financial crisis, which could mean either a creation of hidden reserve or creation of provisions having been absent. (iii) The small companies do not react to the financial crisis anymore.

4 The Income tax provisions were used in the case of period $2004-2010$, the GDP in the case of period $2005-2011$. 
Tab. 8: Number of disclosed other provisions

\begin{tabular}{|l|r|r|r|r|}
\hline Companies & \multicolumn{1}{c|}{ A } & \multicolumn{1}{c|}{ B } & \multicolumn{1}{c|}{ C } & D \\
\hline Large & $72.87 \%$ & $72.15 \%$ & $73.60 \%$ & $115.79 \%$ \\
\hline Middle-sized & $38.76 \%$ & $33.98 \%$ & $43.58 \%$ & $131.52 \%$ \\
\hline Small & $6.92 \%$ & $9.39 \%$ & $5.10 \%$ & $36.08 \%$ \\
\hline
\end{tabular}

Source: SOLIDITET, S.R.O. (2013), authorial computation

Explanatory notes: $\mathrm{A}=$ Geometrical mean for the period $(2004-2011)$, $\mathrm{B}=$ Geometrical mean for sub-period 2004 -2007; C = Geometrical mean for sub-period 2008 - 2011; D = Comparison 2011/2004

This type of provisions represents about one half of the total amount of provisions in large companies (the trend is increasing, it is $60.1 \%$ in 2011). It was one half of the total amount of provisions of middle-sized companies at the start of the period as well. However, due to the reduction of provisions under special legislation, the amount of these provisions increased up to $90 \%$ at the end of the period. Very similar situation was observed in small companies (between 60\% and 80\% for the period 2004 - 2007 and $100 \%$ for the period 2008 - 2011). This analysis shows that the companies recognized other provisions together with one or more next types of provisions. Due to the change of legislation, the amount of other provisions increased regularly.

\section{Conclusion}

The research of provisions in metallurgical industry showed the development of this accounting category in financial statements of companies. We can make some interesting findings:

1. The number of financial statements containing provisions is descending. Companies reduce recognizing and disclosing of provisions. However, influence of the financial crisis was not detected immediately. The main reason for the descending trend of provisions is changed legislation - the new act 593/1992 Cool. which requires saving money in the amount of the provision on a special bank account. However, the descending trend is visible even if excluding the provisions under legislation. The correlation analysis shows dependence on the GDP of the Czech Republic and the Member States of the European Union. The dependence on the GDP of the Czech Republic is visible especially in the small companies. 
2. Provisions are disclosed mainly by larger companies. The large companies kept the number of disclosed provisions on the approximately same level during the whole period. The middle-sized companies disclose provisions in less financial statements, however, the disclosure was not influenced by any analyzed factors. The small companies showed a descending trend of disclosure of provisions, especially in the second sub-period.

3. The amount of provisions is the most important for small companies. The importance for large and middle-sized companies is almost the same and minor than for the small ones. However, the amount of provisions was reduced by all the companies during the period. The reduction of amount of provisions was caused by the category of provisions under special legislation.

4. The financial crisis influenced mainly small and middle-sized companies. They started to reduce the amount of provisions after beginning of financial crisis. The reduction was important especially for small companies. The middle-sized companies reduced the amount of liabilities and the amount of provisions in the same proportion, whereas small companies reduced the amount of provisions even more than amount of liabilities. This situation was discovered in spite of excluding the provisions under special legislation for the judgment.

5. The provisions under special legislation descended very quickly across the companies' size. We can draw the conclusion that this type of provisions is recognized only to meet the tax effect of these provisions.

6. Small companies generally recognize only one type of provisions the trend is visible for provisions under special legislation, other provisions and income tax provisions. This trend was backed due to the change of legislation and the reduction of provisions under special legislation.

7. The number of financial statements disclosing income tax provisions showed positive correlation with the future development of the GDP of the Czech Republic in case of large and middle-sized companies.

The most important finding is that the companies try to reduce the number of disclosed provisions. However, they have to recognize all the future expenses which can occur. The provisions can be typically found in financial statements of large companies. The influence of financial crisis was detected only for small and middle-sized companies. The small 
companies cut the number and the amount of provisions immediately. These conclusions are important for appraisers because of the value of liabilities of companies and for auditors who have to be more careful when auditing this accounting category.

\section{References:}

[1] Bobek, M. (2012): Účetní rezervy podle ČÚS a IAS/IFRS včetně empirické studie vykazování. Český finanční a účetní časopis, December 2012, vol. 7, no. 2, pp. 66-92.

[2] Boston Consulting Group (2007): Beyond the Boom - The Outlook for Global Steel. [on-line], Boston, Boston Consulting Group, c2007, [cit.: $29^{\text {th }}$ September 29, 2013], <http://www.bcg.pt/documents/file14947.pdf>.

[3] Czech Statistical Office (2013): Macroeconomics Table of the Czech Republic. [on-line], Prague, Czech Statistical Office, c2013, [cit.: $2^{\text {nd }}$ October, 2013],

<http://www.czso.cz/csu/redakce.nsf/i/cr:_makroekonomicke_udaje/ \$File/HLMAKRO.xls>.

[4] Czech Statistical Office (2013a): External Trade, January - December 2012. [on-line] Prague, Czech Statistical Office, c2013 [cit.: $4^{\text {th }}$ October, 2013],

<http://www.czso.cz/csu/2012edicniplan.nsf/t/09003EE374/\$File/60 01121201.pdf $>$.

[5] ECORYS SCS Group. (2008): Study on the Competitiveness of the European Steel Sector. [on-line], Rotterdam, ECORYS SCS Group, c2008, [cit.: $29^{\text {th }}$ September, 2013],

$<$ http://ec.europa.eu/enterprise/sectors/metals-minerals/files/final_re port_steel_en.pdf>.

[6] Ernst \& Young (2013): Global steel 2013: A new world, a new strategy. [on-line], Ernst \& Young, c2013, [cit.: $29^{\text {th }}$ September, 2013], <http://www.ey.com/Publication/vwLUAssets/Global-Steel-Report2013/\$FILE/Global-Steel-Report-2013_ER0046.pdf>.

[7] Eurostat (2013): Real GDP Growth Rate - Volume. [on-line], Luxembourg, Eurostat, c2013, [cit.: $2^{\text {nd }}$ October, 2013], $<$ http://epp.eurostat.ec.europa.eu/tgm/table.do?tab=table\&init=1\&plu gin $=1 \&$ language $=$ en $\&$ pcode $=$ tec $00115>$. 
Bobek, M.: Provisions in Metallurgical Industry and Financial Crisis.

[8] Hutnictví železa. (2013): Úvodní charakteristika. [on-line] Prague, Hutnictví železa, c2013, [cit.: $29^{\text {th }}$ September, 2013], <http://www.hz.cz/cz/uvodni-charakteristika>.

[9] IASB (2012): IAS / IFRS International Financial Reporting Standards. [on-line], London, International Accounting Standards Board, c2012, [cit.: $10^{\text {th }}$ September, 2012],

<p://eur-lex.europa.eu/LexUriServ/LexUriServ.do?uri=OJ:L:2008:32 0:0001:0481:EN:PDF>.

[10] Ministry of Industry and Trade (2013): Financial Analysis of Business with the Emphasis on the Competiveness of Sectors in 2012. [on-line], Prague, Ministry of Industry and Trade Czech Republic, c2013, [cit.: $5^{\text {th }}$ October, 2013], <http://www.mpo.cz/dokument141226.html>.

[11] Ministry of Labor and Social Affairs (2007): Důchodová reforma přichází včas. [on-line], Prague, Ministry of Labor and Social Affairs Czech Republic, c2007, [cit.: $6^{\text {th }}$ October, 2013], <http://www.mpsv.cz/cs/4380>.

[12] SOLIDITET (2013): Albertina database. [database], Praha, Soliditet, c2013, [cit.: $23^{\text {rd }}$ February 2013 and $30^{\text {th }}$ September 2013].

[13] World Steel Association (2012, April). Key facts about the World Steel Industry. [on-line], Brussels, World Steel Association, c2012, [cit.: $29^{\text {th }}$ September, 2013], <http://www.worldsteel.org/media-centre/key-facts.html>.

[14] Zámečník, P. (2007): Di̊chodová reforma je na světě! Praha, Mesec.cz, c2013, [cit.: $6^{\text {th }}$ October, 2013], <http://www.mesec.cz/clanky/duchodova-reforma-je-na-svete/>. 


\title{
Provisions in Metallurgical Industry and Financial Crisis
}

\author{
Michal BOBEK
}

\begin{abstract}
The article studies the provisions in the metallurgical industry - the number of financial statements disclosing provisions and the amount of provisions disclosed in financial statements. The aim of article is both to presents the provisions disclosed in the financial statements and to determine the influence of financial crisis on the disclosing of provisions in this industry. The individual types of provisions are analyzed as well. The individual types of provisions are researched concerning the number of disclosed provisions and amount of them.
\end{abstract}

Key words: Provisions; Metallurgical Industry; Financial Crisis; Czech Republic.

JEL classification: M41, M19. 